\title{
Mobility Biopolitics and the Aquarium as a Paradigm of Political Space ${ }^{1}$
}

\section{Jinhyoung Lee}

\begin{abstract}
This paper examines Namcheon Kim's novel The Aquarium of Love and, using Japanese colonialism as an example, identifies the aquarium as a paradigm of political space in terms of the right to mobility. It pays special attention to mobility biopolitics which a colonial biopower imposes upon the colonized lives by managing their mobilities, redefining the threshold in life. In the novel, Kim describes colonial Korea as a mobile society composed of citizens with the right to mobility and non-citizens without it, and as a colonial-political space in which a colonial biopower excludes (probably) threatening mobilities from society for the maintenance of the colonial regime. In the colonial-political mobile space, non-citizens, including the poor and the threats, are identified as lives devoid of value. At the same time, by utilizing an aquarium as a paradigm of political space, Kim characterizes citizens in the colonial society as fish in an aquarium, who (un)consciously practice "sheer political thoughtlessness," restricting their movements within "animal reaction and fulfillment of functions." Thus, as the colonized, citizens and non-citizens are homogenized equally as the bare life deprived of political rights, that is, the sacred life. Thus, the aquarium discloses the colonial space's insubstantiality originating from the categorical exclusion of political subjects, which then encourages the politics of "more than" to seek the decolonized-humanized formation of society.
\end{abstract}

Keywords: Aquarium paradigm, Japanese colonialism, mobility biopolitics, Namcheon Kim, politics of "more than"

${ }^{1}$ This work was supported by the Ministry of Education of the Republic of Korea and the National Research Foundation of Korea (NRF-2018S1A6A3A03043497).

(C) 2021 Jinhyoung Lee

https://www.kritike.org/journal/special issue 2021/j lee2 april2021.pdf

ISSN 1908-7330 


\section{The Right to Mobility and Japanese Colonialism}

7 his paper examines Namcheon Kim's novel The Aquarium of Love (1939-1940) and identifies the aquarium as a paradigm of political space in relation to the right to mobility, using Japanese colonialism (1910-1945) in the Korean Peninsula as its example. It pays special attention to mobility biopolitics which a colonial biopower imposes upon the colonized lives by managing their mobilities. In the novel, a colonial biopower molds the colonized differently: its citizens with the right to mobility and its noncitizens without it. However, neither the citizens nor the non-citizens have political rights in colonial society. Like fish in an aquarium, they are homogenized as the bare life devoid of value, that is, the sacred life. Thus, the aquarium paradigm discloses the colonial-political space's insubstantiality, which originates from its categorical exclusion of political subjects.

The right to mobility has been regarded as an expansion of human rights. Act 13 of the United Nations Universal Declaration of Human Rights (1948) stipulates free movement within and beyond the borders of each State as a human right. Thus, the right to mobility is considered a fundamental right that ensures access to housing, employment, education, and culture, ${ }^{2}$ and philosophically integrates the ideas of personal mobility and freedom. ${ }^{3}$ However, as John Urry critically pointed out, focusing on the right to move as simply "the freedom from" can result in the fetishization of movement through unconditioned affirmation and pursuit of mobility and its development by identifying it with the progress of human rights. ${ }^{4}$

More noteworthy, Tim Cresswell argued that, by the logic of "othering," the right to mobility shaped citizens and others simultaneously, by focusing on the creation of American citizenship. ${ }^{5}$ For example, Chinese migrant workers working on railroad construction sites in the United States are excluded from American citizenship; they were treated as aliens, and denied the freedom of movement, thereby strengthening a boundary between citizens and non-citizens. By extending Cresswell's problematique in her book, Mobility Justice (2018), Mimi Sheller placed the understanding of the freedom of movement outside the liberal narrative of "presumed rights-bearing individuals," demanding the consideration of the profound inequality and

\footnotetext{
2 See Jean-Pierre Orfeuil, "The 'Right to Mobility', Now and in the Future," in Mobile/Immobile: Quels Choix, Quels Droits pour 2030 1, ed. by Christophe Gay, Sylvie Landriève, and Stéphanie Vincent-Geslin (La Tour d'Aigues: Éditions de l'Aube, 2011), 49.

${ }^{3}$ See Jean Viard, "Mobility, the Culture of Modern Times," in Mobile/Immobile: Quels Choix, Quels Droits pour 2030 2, ed. by Christophe Gay, Sylvie Landriève, and Stéphanie VincentGeslin (La Tour d'Aigues: Éditions de l'Aube, 2011), 56.

${ }^{4}$ John Urry, Mobilities (Cambridge: Polity, 2007), 207.

${ }^{5}$ Tim Cresswell, "The Right to Mobility: The Production of Mobility in the Courtroom," in Antipode, 38 (September 2006), 751-752.

(c) 2021 Jinhyoung Lee

https://www.kritike.org/journal/special issue 2021/j lee2 april2021.pdf

ISSN 1908-7330
}

(c) BY-NC-ND 
exploitation of others therein, "the fundamental basis of the freedom of movement in the domination of the bodies of others, whether female, animal, or slave." ${ }^{6}$ Hence, the right to mobility cannot be viewed simply in terms of human rights. Instead, it should be reconceptualized as a paradoxical construct, composed of the freedom of movement and its denial, which molds citizens and non-citizens at the same time.

The right to mobility demonstrates an aspect of biopolitics, to use Giorgio Agamben's terminology, that inscribes natural lives in the juridicopolitical order of the nation-state by managing their mobility and categorizing them as citizens or non-citizens. For Agamben, modern biopolitics does not recognize as the nation-state's basis "man as a free and conscious political subject," but "man's bare life, the simple birth that as such is." 7 At the same time, it constantly redefines "the threshold in life" that separates "what is inside" from "what is outside," 8 that is, a citizen from a sacred life, homo sacer, as "life devoid of value." 9 In short, while setting bare life as the premise for a nation-state, modern biopolitics molds citizens, assigns the freedom of movement inside the nation-state, and identifies noncitizens, such as refugees and prisoners who are not allowed freedom of movement, as "devoid of value." Accordingly, the right to mobility attests to the actualization of biopolitics via mobility, that is, a mechanism of mobility biopolitics: biopower is exercised by managing citizens' movements while sorting the valueless (im)mobilities of non-citizens, the sacred lives-i.e., for Sheller, female, animal, or slave.

Recalling Takashi Fujitani's arguments, Japanese colonialism transformed its discrimination against Koreans from the exclusive "vulgar racism" to the inclusive "polite racism" in order to mobilize them to fight in the Sino-Japanese War (1937) and the Pacific War (1941). Thus, colonial policies toward Koreans were crafted to make them into "a major subpopulation" by improving their health and sanitary conditions and raising their birthrate. More precisely, colonial biopower was used to constitute living beings' aggregate as a subpopulation by separating "who must live" from "who must die," "those who will foster the life and welfare of the population" from "those considered threats" and thus must be killed or expelled. ${ }^{10}$ For example, while incarcerating a thousand political offenders by enforcing the thought control policy, ${ }^{11}$ the colonial government announced

${ }^{6}$ Mimi Sheller, Mobility Justice (London: Verso, 2018), 49-50.

7 Giorgio Agamben, Homo Sacer, trans. by Daniel Heller-Roazen (Stanford: Stanford University Press, 1998), 127-128.

${ }^{8}$ Ibid., 131.

${ }^{9}$ Ibid., 139

${ }^{10}$ Takashi Fujitani, Race for Empire (Berkeley: University of California Press, 2011), 38-40.

${ }^{11}$ In the Second Sino-Japanese War in 1937, the colonial government launched the National Spiritual Mobilization Movement Campaign (1938-1940) to mobilize the support of the 


\section{MOBILITY BIOPOLITICS}

the enforcement of the "naisen-ittai" (內鮮一體; Japan and Korea as one body) in 1936, aimed at the Japanization of Korea, which could thus be (mis)construed as the abolition of the domination by Korean intellectuals. ${ }^{12}$ For the colonial regime's maintenance, Japanese colonialism, on the one hand, organized citizens mobile as its subpopulation and the valuable life, and, on the other hand, identified non-citizens immobile as the valueless or threats, redefining the threshold in life.

The citizen can underpin the existent political regime by circulating freely inside society, where biopower "can only be carried out through and by reliance on the freedom of each," as Michel Foucault said. ${ }^{13}$ In colonial Korea, the word "citizen" was often used to signify people engaged in everyday economic activities by enjoying the freedom of movement at the expense of political rights. ${ }^{14} \mathrm{By}$ asserting the right to circulate freely inside the society, citizens could be separated from non-citizens, whose mobilities were not allowed in colonial society due to their valuelessness or probable minaciousness. ${ }^{15}$ However, it is notable that, as colonized beings, neither the citizens nor the non-citizens have political rights; in other words, their authority of life-and-death was surrendered to the colonial biopower. That is,

colonized for the war, while enforcing the Public Peace Maintenance Law in 1925, imprisoning even moderate nationalists who were denounced as thought criminals. Jeongmok Son, A Study on the Urban Society under the Japanese Occupation (Seoul: Iljisa, 1996), 148-172.

12 Minami Jiro (南次郎), appointed as the Japanese governor-general of Korea in 1936, implemented the "naisen-ittai," setting it as the most urgent national polity. Its purpose was to establish the Koreans' and the Japanese' spiritual identity through the former's sharing of the Loyal Japanese Subject spirit. Specifically, to this end, the Japanese Government-General of Korea enacted the Army Special Volunteer System (1938), the Third Chosen Educational Ordinance (1938), the Japonification of Korean Names (1940), among others. However, it also adhered to the juridical division and inequality between both by disciplining them according to the different legal systems, respectively, denying their juridical unification. Nevertheless, by assuming their substantial equality and unification, Korean intellectuals sometimes demanded their equal obligations and political rights to the colonial authority. Seungil Lee, Legislative Policy of the Japanese Government-General of Korea (Seoul: Yuksabipyeongsa, 2008), 11; Myunggoo Kim, "The Acceptance and Its Logic of 'Naeseon Ilchae' Theory/Propaganda in Joseon during the Period of the Sino-Japanese War," in The Journal for the Studies of Korean History, 33 (November 2008), 381-388.

${ }^{13}$ In Security, Territory, Population, Foucault elaborates "a physics of power" which "can only be carried out through and by reliance on the freedom of each," that is, "freedom of circulation," including "the possibility of movement, change of place, and processes of circulation of both people and things." Michel Foucault, Security, Territory, Population, ed. by Michel Senllart, trans. by Graham Burchell (New York: Picador, 2007), 48-49.

${ }^{14}$ In colonial Korea, the notion of the citizen was involved mainly in private freedom and right. Thus, the political movements and activities were unfolded mostly in the names of nation and class. Myoungkyu Park, Nation, People, and Citizen (Seoul: Sowha, 2009), 219-231.

${ }^{15}$ For instance, the colonial government organized the mobile police, who had worked mainly in the train and ship, to supervise Korean activists' movements. Shin Jang, "Travel Forbidden in Joseon under Japanese Occupation: A Study on the Transit Police," in Journal of Humanities, 25 (August 2017), 115-143.

(c) 2021 Jinhyoung Lee

https://www.kritike.org/journal/special issue 2021/j lee2 april2021.pdf

ISSN 1908-7330

(cc) BY-NC-ND 
in colonial Korea, whether citizens or non-citizens, both were the colonized. Thus, mobility biopolitics in the colony ultimately recognizes both equally as the bare life, as a basis of the colonial regime; ergo, the homo sacer, deprived of political rights. ${ }^{16}$ In this regard, Ann Laura Stoler defines the "colony" as "a principle of managed mobilities, mobilizing and immobilizing populations according to a set of changing rules and hierarchies that orders social kinds." 17

Drawing from these theoretical reflections, this paper explores Kim's novel, The Aquarium of Love, which was serialized from August 1, 1939 to March 3, 1940 in the Korean daily newspaper Chosunilbo. Narrating Kwangho Kim and Kyunghee Lee's love story from their first encounter at the railroad construction site, their movements within and beyond a border, and their eventual marriage, this novel depicts the reality of Korean colonial society. ${ }^{18}$ Significantly, it portrays colonial Korea as the mobile society, in which citizens can enjoy the freedom of movements but non-citizens cannot; also, the colonial-political space, in which the colonial biopower expels threatening mobilities from society for the colonial regime's maintenance.

Kim's novel allows us to discern the mechanism of mobility biopolitics through which Japanese colonialism exercises its biopower, managing the colonized lives' mobilities, thereby not only making citizens mobile and non-citizens (probably) immobile, but also homogenizing both as fish, the sacred lives devoid of value. Using the aquarium as a paradigm of political space, Kim characterizes citizens moving in the society as fish swimming in an aquarium, who are empowered with the freedom of movement at the expense of political rights, (un)consciously practicing "sheer political thoughtlessness," thus restricting their movements within "animal reaction and fulfillment of functions." The aquarium paradigm highlights the homogeneity of citizens and non-citizens as the colonized, the bare life deprived of political rights. Thus, it discloses the colonial space's insubstantiality, which originates from the categorical exclusion of political

${ }^{16}$ Gyanendra Pandey denominated citizens deprived of the political right as "subaltern citizens" who are "materially more comfortable citizens" but "not allowed to be part of the polis." Gyanendra Pandey, "Introduction: The Subaltern as Subaltern Citizen," in Subaltern Citizens and Their Histories, ed. by Gyanendra Pandey (New York: Routledge, 2010), 4. Despite the usefulness of this theory in identifying colonial Koreans who demanded their political rights, this paper will use the definition of "citizen" to maintain Agamben's conceptual classification of citizen and non-citizen.

${ }^{17}$ Ann Laura Stoler, Duress: Imperial Durabilities in Our Times (Durham: Duke University Press, 2016), 117. (Original emphasis.)

${ }^{18}$ Hyerim Choi has pointed out the coincidence of the time in the novel and the real-time in Kim's work, focusing on the contemporaneity of events in the novel and news in the daily newspaper the work had been serialized. Hyerim Choi, "A Study on the Meaning of Everyday Life Represented in Sarang-Eui Sujokwan (The Aquarium of Love) Written by Nam-Cheon, Kim," Journal of Korean Literary History, 25 (2004), 253.

(c) 2021 Jinhyoung Lee

https://www.kritike.org/journal/special issue 2021/j lee2 april2021.pdf

ISSN 1908-7330 


\section{MOBILITY BIOPOLITICS}

subjects from inside, thereby encouraging us to ponder the politics of "more than" that seeks the decolonized-humanized formation of society.

The next section presents Korean society in the 1940s as a mobile society, which cultivates citizens mobile, the valuable lives, and non-citizens immobile, the sacred lives. Moreover, this paper focuses on a colonialpolitical space where mobility biopolitics governs colonial society by expelling threatening mobilities from society, characterizing them as the political. Afterward, it proposes the aquarium as a paradigm of political space. This paradigm critically views the barrenness and insubstantiality of the colonial-political space as a consequence of its categorical exclusion of political subjects, in which not humans but fish, animal-like beings, solely can survive. Concludingly, this paper ponders an alternative to colonial mobility biopolitics, that is, the politics of "more than."

\section{The Mobile Society, Citizens, and Non-Citizens}

While serializing The Aquarium of Love, Namcheon Kim executed his theoretical investigation of the novel as a genre by publishing a series of essays, "Research Notes on Balzac" from October 1939 to May 1940.19 For Kim, Balzac was a realist who captured the spirit of $19^{\text {th }}$-century Paris by describing mostly bourgeois characters who mainly seek money in capitalist society. ${ }^{20}$ Central to his work was "a milieu," a social environment considered a cultivator of the bourgeois. ${ }^{21}$ Based on this understanding, Kim argued that Korean writers should describe "the historical epitome of human society" by portraying the social environment of colonial Korea. ${ }^{22}$

Kim's novel can be read as an attempt to seize on "the historical epitome of human society," focusing on the romance between Kwangho Kim and Kyunghee Lee. ${ }^{23}$ In an interview with Chosunilbo, he admitted that he had written the novel to reflect contemporary Korean society through the

19 The series of "Research Notes on Balzac" published in Inmunpyungnon [Humanistic Criticism] consists of four pieces: "Le Pere Goriot, Father's Love, and the Like," Inmunpyungnon 1 (October 1939); "Problems of Character and Monomania," in Inmunpyungnon 3 (December 1939); "Essay on the Literature of Observation," in Inmunpyungnon 7 (April 1940); and "The Experienced and the Observed," in Inmunpyungnon 8 (May 1940).

${ }^{20}$ Namcheon Kim, "Problems of Character and Monomania," in Namcheon Kim's Collected Works, ed. by Ho-Ung Jung and Jeong-Soo Son (Seoul: Pagijong Press, 2000), 550.

${ }^{21}$ Ibid., 552.

${ }^{22}$ Namcheon Kim, "Essay on the Literature of Observation," in Namcheon Kim's Collected Works, ed. by Ho-Ung Jung and Jeong-Soo Son (Seoul: Pagijong Press, 2000), 597-599.

${ }^{23}$ After its serialization in the Korean daily newspaper, the work was published in book form in November 1940 and its second edition in December 1940, which, considering its intention of describing contemporary society, would demonstrate not only its popularity but also its verisimilitude.

(c) 2021 Jinhyoung Lee

https://www.kritike.org/journal/special issue 2021/j lee2 april2021.pdf

ISSN 1908-7330

(c) BY-NC-ND 
struggles of ordinary young people. ${ }^{24}$ To this end, he presented their relationship not as a private emotion or individual behavior but rather as representation of the thoughts and customs of the social groups to which they belong. Thus, The Aquarium of Love first centers on its characters' love affairs.

What is striking in The Aquarium of Love are the relationships among the characters, who most of all seek love as well as money. The male protagonist, Kwangho Kim, is a talented civil engineer. He wants to win the love of Kyunghee Lee, the female protagonist, a university graduate and the daughter of the head of the giant conglomerate in colonial Korea, Daeheung Konzern. While exerting herself to establish a public nursery, Kyunghee Lee also desires to marry him. While her father, Shinkook Lee, aspires to develop his conglomerate, his right-hand man, Hyundo Song, plays a deep game to marry Kyunghee, ultimately occupying Shinkook's company while enjoying immoral intimacy with Kyunghee's new mother. While a friend of Kyunghee, Hyunsoon Kang, a tailor, dreams but fails to win Kwangho's love, Ilsung Shin, Hyunsoon's distant relative, repeatedly courts her at once prowling around, cheating others out of their money. It is through these love affairs, through the relations of those zealously moving to satisfy their desires, that the novel depicts contemporary Korean society.

It is more notable that their relations are formed by depending on and utilizing modern mobility systems. When the novel begins, Kwangho and Kyunghee meet at a railroad construction site in the mountains. They spend a long time traveling through Seoul. At the climax of the novel, she takes a high-speed train, Nozomi [のぞみ], to journey to Manchuria in China. ${ }^{25}$ In addition, the novel repeatedly specifies central figures' travels and means of transportation. For example, Shinkook's daily travels by private luxury cars, Hyundo's business trip abroad by plane, Ilsung's wanders by taxi for deceiving others, and Hyunsoon's routines by tram. In short, Kim's novel represents Korean society around 1940 as a mobile society, where modern mobilities empower people to travel to indulge their desires. In this respect, the mobile society assures the right to mobility.

In Kim's novel, characters' movements allow them to form social relations and fall in love. In other words, they have the right to mobility, which is equated with citizenship, the right to reside inside the mobile

24 "The Aquarium of Love that displays contemporary characters," in Chosunilbo (July 31, 1939).

${ }^{25}$ In this regard, the close association between love and mobility also can be considered. For example, in "'Walking Out': The Mobilities of Love," Lynne Pearce discussed "the significance of mobility in the production, or facilitation, of relationships." Lynne Pearce, “'Walking Out': The Mobilities of Love," in Mobilities, 13 (2018), 2.

(c) 2021 Jinhyoung Lee https://www.kritike.org/journal/special issue 2021/j lee2 april2021.pdf

ISSN 1908-7330 


\section{MOBILITY BIOPOLITICS}

society. ${ }^{26}$ At the same time, the right to mobility creates others who cannot travel freely, whose existences thus become known only mediately. These include construction workers, sex workers, and stay-at-home mothers - that is, the poor. Their inability to travel demonstrates their otherness, prevents them from being part of a mobile society, and relegates them to the status of non-citizens.

The presence of non-citizens is inferred through the conversations among citizens on the move. At the railroad construction site where Kwangho works, Kyunghee hears something about the construction workers. She comes to perceive the presence of prostitutes by chance while on a date with Kwangho. Also, she talks about young mothers while on a walk with him. As immobile beings, the poor exist as the unrepresented in the novel. Despite working in workplaces, existing in a restricted area, or caring for their babies, they are considered non-citizens, immobile and invisible, that is, "what is outside." Unlike citizens with the right to mobility, they are others without it; thus, they are unworthy to visualize materially in the mobile society.

In this regard, striking is the public nursery, which Kyunghee establishes to satisfy her vanity. ${ }^{27}$ In terms of the narrative development, this charitable work constitutively and significantly parallels her courtship and marriage. She says that the public nursery will be constructed in villages so that poor people will be able to work. ${ }^{28}$ Her charitable work is not intended to improve their social status or living conditions but rather to tie them to their workplaces. Also, Kwangho exploits construction workers in the construction site and he is not interested in enhancing their lives. Just like her, he also identifies the poor only as labor forces in a mobile society, thus letting them remain as immobile non-citizens. This immobility makes them not only the unrepresented, but also the valueless lives, that is, the dehumanized, bare lives. In other words, they are the sacred life, homo sacer, which may be killed and yet not sacrificed, as Agamben puts it. ${ }^{29}$ They may be exploited and exhausted in workplaces, not yet considered significant and meaningful.

\footnotetext{
${ }^{26}$ In the novel, Ilsung Shin described "the right of citizen" as access to mobilities enabling citizens to move freely and easily. Namcheon Kim, The Aquarium of Love (Keijo: Inmunsa, 1940), 110 .

${ }^{27}$ In colonial Korea, charitable works were usually discussed as activities for satisfying vanity. Jinsook Park, "The Aspects and Meanings of Textualization in the Novels in the Late Period of Japanese Rule over Korea," in Gaesin Language and Literature Research, 32 (2010), 123 125. By setting Kyunghee's public nursery as an impetuous choice as an equivalent to a study abroad, Kim also characterizes it as an act to satisfy her vanity.

${ }^{28}$ When Kwangho asked Kyunghee about her charitable work, "Why will the poor leave their children to the public nursery?" she answered, "To go to work!" Kim, Aquarium of Love, 169.

${ }^{29}$ Agamben, Homo Sacer, 8.

(c) 2021 Jinhyoung Lee

https://www.kritike.org/journal/special issue 2021/j lee2 april2021.pdf

ISSN 1908-7330
}

(cc) BY-NC-ND 
Thus, a mobile society that assures the right to mobility cultivates citizens mobile and non-citizens immobile, simultaneously. In other words, citizens' movements confirm and (re)produce non-citizens, that is, the sacred lives by practicing the right to mobility, thus materializing the threshold in life. Thus, contemporary Korean society is described as the mobile space, maintained by the dichotomy of life, privileging citizens moving therein, (re)producing non-citizens as the sacred life.

\section{Mobility Biopolitics of the Colonial-Political Space}

In Kim's novel, contemporary Korean society is not exhausted by describing the mobile society, dichotomously composed of mobile citizens and immobile non-citizens. Instead, it portrays the mobile society as the colonial-political space in which colonial biopower governs the colonized lives by managing their mobilities. Thus, mobility biopolitics performs.

It is notable that Kim's mobile society is underpinned by modern mobility systems, which Japanese colonialism established. Before its occupation of Korea (1910-1945), Japanese colonialism briskly participated in the construction of modern mobility infrastructures, including railroads, new roads, and sea routes, within and beyond the Korean peninsula to invade Korea, China, and Russia. After the occupation, it allocated $20 \%$ of the total budget of the Japanese Government-General of Korea - the Japanese colonial government organization inaugurated in 1910 - in the 1910s to constructing an expansive mobility system. Under the "12 Years Plan of Korean Railroad" (1927-1938), the mobility system extended to every corner of the country. ${ }^{30} \mathrm{In}$ Kim's novel, the completion of the mobility systems is suggested in the first scene when railroad construction has progressed deep into the mountains.

As a constructor of the mobile society, Japanese colonialism first is depicted symbolically, as follows:

The sound of the tram, "boo-," turning curvedly in front of the Japanese Government-General of Korea, is heard and, in the Samchung Park directly opposite to it, early morning walkers' shouts are audible, it is the time when the eastern sky is colored with red sunbeams and the movements of the citizens, reawakening from their sleep, make noises at the Jongno crossroads. ${ }^{31}$

${ }^{30}$ Jinhyoung Lee, "Colonial Mobility and the Biopolitics of the Colonial Non-Place," in Kritika Kultura, 36 (2021), 217-220.

${ }^{31} \mathrm{Kim}$, Aquarium of Love, 146.

(c) 2021 Jinhyoung Lee https://www.kritike.org/journal/special issue 2021/j lee2 april2021.pdf

ISSN 1908-7330 


\section{MOBILITY BIOPOLITICS}

In the excerpt, the morning in Seoul, the capital of colonial Korea, begins with the sound of the tram and shouts of people taking early walks, the Japanese Government-General of Korea being their geographical center. Thus, in this mobile society, Japanese colonialism exercises its dominance and reinforces the colonial order by organizing mobilities.

Japanese colonialism is also incorporated into the narrative, organizing the movements of the protagonists. For example, at the start of their courtship, the two protagonists pass by the headquarters of the Japanese Government-General of Korea while on their way home. It happens again when they quarrel and make up; and at the climax, in which Kyunghee returns to Seoul from the countryside to tell her father that she is getting married. Having these crucial scenes take place at the headquarters of the Japanese Government-General of Korea shows colonial power not only constitutes but also manages citizens' everyday mobile lives.

Japanese colonialism exercises its dominance in colonial Korea by erecting modern mobility systems and organizing everyday mobilities, thus empowering citizens to move in search of their desires. In this respect, their freedom of movements perpetuate the colonial regime by confirming and (re)producing the dichotomic structure of the mobile space. In other words, citizens' practice of their right to mobility renders them as subjects in the colonial society. Hence, Japanese colonialism can be considered governing its colony by fostering a social environment ensuring the right to mobility of colonial subjects. In Foucault's words, the right to mobility materializes "the insertion of freedom within governmentality." 32

At the same time, to maintain its colony, colonial power removes from society "those considered threats," who probably or possibly disturb or undermine the colonial regime, redefining the threshold in life, that is, separating "what is inside" from "what is outside." Given citizens' right to mobility as supporting the colonial regime, their unconstrained movements for gratifying their desires are allowed as "what is inside"; on the contrary, politically dubious movements possibly jeopardizing the colonial regime's security are categorized as "what is outside." Therefore, in a colonial-political society, movements because of love, money, and vanity are regarded as freedom of movement. However, political movements must be stopped, the participants killed or expelled from society. Thus, categorically excluding alleged threats from society is colonial biopower's most urgent task.

The death of Kwanjun Kim, Kwangho's older brother, and the expulsion from school of Kwangshin Kim, his younger brother, are examples of categorical exclusion. Kwanjun, about 30 years old, died of acute tuberculosis early in the novel. His last words were, "I am pleased and

${ }^{32}$ Foucault, Security, Territory, Population, 353.

(c) 2021 Jinhyoung Lee

https://www.kritike.org/journal/special issue 2021/j lee2 april2021.pdf

ISSN 1908-7330

(cc) BY-NC-ND 
pleasant that my body becomes unlivable as timely as my usefulness enabling me to live longer gets lost...." 33 His refusal to enter the hospital for treatment allows his death to be interpreted as partially intentional, and as a sign of resistance. As Kwanjun had previously participated in anticolonial or socialist movements, Kwangho commented, "It could not be imagined that, as expected, my older brother threw away his attachment to life. Rather, what threw away is the belief, which can nourish such attachment." 34 In short, regardless of the cause, Kwanjun's death is seen by his brothers as evidence of the uselessness of his political beliefs in the colonial society. As a result, with his secluded life in the barmaid's home as a metaphor of uselessness, his death can be interpreted as the biological expulsion of a valueless life from society; more precisely, the biopolitical exclusion of politically threatening mobility.

The next case is Kwangshin's expulsion from secondary school for alleged misbehavior. He had been cited by an agent of the Guidance League, which supervised Korean students' extramural mobilities. ${ }^{35}$ His teacher reports that Kwangshin had been spied walking in a public park together with a barmaid, Yangja Park, who is also his elder brother's girlfriend. After asserting that "What matters is his ideology. It is his spirit," 36 his teacher says, "Then, had his uncle been caught by a rebellious ideology once?" 37 and explains that he will be expelled for his rebellious idea not just for his misbehavior. As the teacher accuses him of having made threatening gestures in school, like his late brother's resistance, he sees Kwangshin's deviant mobility as the embodiment of seditious ideology, influenced by his older brother-as Kwangshin utters, "the ones who can understand my elder brother are exclusively the barmaid and me." 38 Like Kwangjun's death as the biopolitical exclusion from society, Kwangshin's life, closely linked to his elder brother's death, is regarded as "what is outside." In short, his expulsion can be understood as the biopolitical exclusion of political mobility as a threat.

These examples demonstrate the way that colonial biopower dominates its colony by separating valuable mobilities from valueless mobilities, thereby politically threatening mobilities. In other words, it governs the colonized lives by separating citizens from non-citizens,

\footnotetext{
${ }^{33} \mathrm{Kim}$, Aquarium of Love, 66.

${ }^{34} \mathrm{Ibid} ., 70$.

35 The Japanese Government-General of Korea wanted to control Korean students by creating the Guidance League in 1933 because students had participated in anti-colonial movements. Hye-Young Hwang, "Gyeong Seong Guidance League's Establishment and Management during the 1930s-1940s," in Yeoksa Yeongu, 22 (June 2012), 204-205.

${ }^{36} \mathrm{Kim}$, Aquarium of Love, 232.

${ }^{37} \mathrm{Ibid}$.

${ }^{38} \mathrm{Kim}$, Aquarium of Love, 56.
} 


\section{MOBILITY BIOPOLITICS}

redefining the threshold in life and considering political mobilities as threats. Thus, it produces threats as non-citizens. Naturally, colonial biopower will kill or expel the latter from society by categorizing them as non-citizens which should be outside. Due to the Kwanjun's and Kwangshin's valuelessness, their death and expulsion, respectively, do not engender grief or anger even from their families or friends. Instead, they are merely portrayed coldly or philosophically from the viewpoint of their brother, Kwangho. That is, their life and death have no value in colonial society. The threshold in life is established firstly between citizens and others, the poor, and then between citizens and non-citizens, those considered threats. In colonial society, they are the sacred life devoid of value.

Japanese colonialism exercises its power by constructing, organizing, and managing mobilities and by expelling non-citizens. While enhancing citizens' lives by assigning them the right to mobility, it produces and excludes the poor and threats from society, categorizing them as non-citizens, as the sacred lives devoid value. That is, Japanese colonialism governs its colony by redefining "the threshold in life," recategorizing citizens as "who must live" and "who must die." In this respect, the right to mobility and the expulsion of threats from society converges in the mobility biopolitics, which, via the right to mobility, (re)creates citizens as "who must live" and "who must die." Thus, the mobile society is the colonial-political space in which citizens' right to mobility is the embodiment of mobility biopolitics.

\section{The Aquarium as a Paradigm of Political Space}

Notably, Kim uses the metaphor of the aquarium for society and swimming fish for traveling citizens. The chapters of the novel are "A Sweet Fish is in the Mountain," "The World Carp Lives," "A Deep-Sea Fish," "A Tropical Fish," "A Couple of Fish Find Romance," "A Chief Whale's Realism," “Ornamental Fish's Romanticism," "A Freshwater Fish's Eyesight," "Cutlassfish," "Happy New Year of Fish," "Mudfish and Dragon Fruit," "Wandering Goldfish," and "Spring Is in the Aquarium." In Korean society, citizens, like fish, travel to satisfy their desires and form social relationships. ${ }^{39}$ Thus, the aquarium as a metaphor connotes the mobile nature of the colonial society. Simultaneously, given the mobile society as the colonial-political space, the aquarium can be considered a paradigm of political space, from which the colonial space is viewed critically as forcing the colonized, both citizens and non-citizens, to be fish-like-beings.

${ }^{39}$ In 1940, colonial Seoul had a population of 935,464 and 154,687 Japanese residents. Despite the high percentage of Japanese (16.54\%), Kim rarely makes them his central characters. The Aquarium of Love also does not have Japanese characters because it is a novel about Koreans.

(c) 2021 Jinhyoung Lee

https://www.kritike.org/journal/special issue 2021/j lee2 april2021.pdf

ISSN 1908-7330

(c) $)$ BY-NC-ND 
As shown in the previous section, colonial biopower includes seemingly apolitical mobilities seeking indulging desires and, on the contrary, excludes political mobilities. Thus, practicing apolitical mobility is an essential prerequisite for citizens moving in society, which leads to their (un)conscious ignorance of their politicization. However, their indifference in politics would not allow them to survive only as mobile citizens but also as bare lives deprived of political rights. In other words, they are mobile bare lives, who, like swimming fish, can travel in search of desires but, like fish in an aquarium, should surrender their authority of life-and-death to the biopower in the colonial-political space. In the aquarium as the colonialpolitical mobile space, citizens are paradoxical colonial subjects who selfconsciously move apolitically but thereby reinforce the colonial regime as their stronghold.

For instance, in criticizing Kyunghee's plan to open a public nursery, Kwangho confesses philosophy of life:

Be that as it may, it is a matter of fact even that I don't have any ideology or ism. I didn't think so regarding your work from a standpoint I have. I sometimes recall my older brother passed away. Of course, I didn't sympathize with his thought or ism and even now don't want to be in his position; however, his influence seems to remain in my thinking. My callous attitude toward charitable work or similar businesses is like a legacy received from him, although I don't know what exactly what the legacy means. However, I am not a malicious nihilist you might imagine concerning me. First, I can be devoted to my duty. I have never been profoundly sceptical of my work, but I am not sure of the reason. For what do I lay the railway? To what are my knowledge and technique used? I have asked these questions. Yet, I quickly managed to shake such thinking off. For I thought as follows: While inventing electricity, Edison probably did not consider that it would be used for homicide; even if he knew such usage, he must not suspend his work of invention. ${ }^{40}$

Drawing on Hannah Arendt's notion of "sheer thoughtlessness," to describe Adolf Eichmann, who "never realized what he was doing," 41 this

\footnotetext{
${ }^{40} \mathrm{Kim}$, Aquarium of Love, 251-252.

${ }^{41}$ Hannah Arendt, Eichmann in Jerusalem (London: Penguin Books, 2006), 287. (Original emphasis.)
}

(c) 2021 Jinhyoung Lee

https://www.kritike.org/journal/special issue 2021/j lee2 april2021.pdf

ISSN 1908-7330 


\section{MOBILITY BIOPOLITICS}

passage stresses the necessity of "sheer thoughtlessness" as an essential prerequisite for making a living, conducting the railroad construction and most of all satisfying his desire for love. By acknowledging the legacy from his dead older brother, Kwangjun, the "callous attitude toward charitable work," while ruling out Kwangjun's political thought, Kwangho justifies his philosophy of life that, like Edison, does not extend beyond the call of duty. Notably, he probably is conscious that his work is utilized for political and military purposes, when he says that "One who dominates oils today is the one who will dominate the world tomorrow" 42 and that "the railway is material to transport coals. On the contrary, an engineer doesn't ask to which end oils are employed." 43 Given historical conditions of wartime between the Sino-Japanese War (1937) and the Pacific War (1940), the public works, conducted according to Japanese imperialistic planning, must be utilized for its political-military purpose. When thought control policy was severely implemented, ${ }^{44}$ shaking political thinking off would be a necessary qualification for a citizen.

In this regard, the narrator remarkably overemphasizes the protagonists' involvement in Japanese national businesses, such as establishing the public nursery and developing artificial petroleum; that is, they are incorporated into the narrative disproportionately and artificially. At the climax, the tension concerning the protagonists' love affair is heightened when three letters from the hero to the heroine was excessively lengthy with nine pages, focusing not on the ease of their tension but the successful development of artificial petroleum in Manchuria, ${ }^{45}$ of which Kwangho's work of the railroad construction is part. Thus, after receiving the letters, Kyunghee throws them into the wastebasket. Also, at the concluding scene, where they talk about their marriage, the hero suddenly demands her to devote her whole finance to organizing social work, including public nursery business as its qualification, which she accepts. Given that the colonial government endorsed public nurseries from the mid-1920 and especially

\footnotetext{
$42 \mathrm{Kim}$, Aquarium of Love, 484.

${ }^{43}$ Ibid., 485.

${ }^{44}$ Around 1940, the colonial government implemented policies to commandeer the colonized and natural resources for military purposes. In 1940, it implemented the Japonification of Korean names, suspended the Korean newspapers, Dong-A Daily News and Chosunilbo, and forcedly transformed Koreans into loyal Japanese subjects.

${ }^{45}$ By enforcing the "7 Years Plan of Artificial Petroleum" in 1937, Japanese imperialism began securing petroleum to compensate for the oil shortage and to prepare for war. Yunmi Kim, "Wartime Munitions Securement and Korean Labor Mobilization," in The Historical Association for Soong-Sil, 25 (2010), 207-210.

(c) 2021 Jinhyoung Lee https://www.kritike.org/journal/special issue 2021/j lee2 april2021.pdf ISSN 1908-7330
}

(c) BY-NC-ND 
around $1940,{ }^{46}$ the concluding scene proves their (un)conscious commitment to the national business.

Considering colonial subjects' ignorance of the colonial-political nature or usage of their businesses, artificially overemphasizing their involvement in the national businesses can be read as disclosing their paradoxical way of being: the entirely political nature of their seeming apolitical movements seeking desires, attained by their "sheer political thoughtlessness." In order to survive in colonial Korea, or not to be expelled from it, they should be those who never realized what they were doing. In other words, their paradoxicality can be deemed the effect of the colonialpolitical constitution of the mobile space adjuring the colonized to be depoliticized by depriving them of political rights.

Therefore, Arendt's insight that "men insofar as they are more than animal reaction and fulfillment of functions are entirely superfluous to totalitarian regimes" 47 can be applied to the colonial-political space. Depending on her insight, citizens' paradoxical being can be considered originating from the restriction of their movements within "animal reaction and fulfillment of functions" in the colonial society, which prevents them from being political subjects and which instead permits them to enjoy the freedom of movement solely as animals. Hence, despite their possible separation from non-citizens, they are not ultimately heterogeneous with the poor or threats by (un)consciously scorning their politicization and at once consenting to their animal nature. Although mobility biopolitics separates citizens from non-citizens, "what is inside" from "what is outside," their absence of political rights allows them to be categorized equally as the colonized. Thus, as the colonized, both citizens and non-citizens can be identified as living beings deprived of political rights, homo sacer; that is, the sacred animals who have surrendered their authority of life-and-death to colonial biopower.

Agamben's description of the camps as a paradigm of political space "at the point at which politics becomes biopolitics and homo sacer is virtually confused with the citizen" 48 helps specify an aspect of the political space under the Japanese colonial rule; where the colonial biopower manages the colonized populations' lives by including or excluding them to or from society, ultimately manufacturing them homogeneously as homo sacer. Meanwhile, Kim's novel describes not just the biopolitical but also the colonial and mobile space, where colonial biopower governs the colonized

\footnotetext{
${ }^{46}$ Yunjin Lee, "The Viewpoint of Women through Child-Care Policy during Japan's Occupation of Korea," in Journal of Asian Women's Studies, 42 (2003), 303-307.

${ }^{47}$ Hannah Arendt, The Origins of Totalitarianism (San Diego: Harcourt Brace Jovanovich, 1976), 457.

${ }^{48}$ Agamben, Homo Sacer, 171. (Original emphasis.)
} 


\section{MOBILITY BIOPOLITICS}

lives via the right to mobility by assigning or retrieving the freedom of movement to or from them. Thus, when it comes to the colonial-mobile society, the aquarium seems more relevant than the camp to describe the political space in which mobility biopolitics performs, a space in which the colonized, as citizens, commit to the colonial regime by possibly enjoying the freedom of movement, at once finding non-citizens. Simultaneously, as fish and homo sacer, citizens approve their lives' bareness, that is, their dehumanization due to their absence of political rights by (un)consciously ignoring their politicization. From the aquarium paradigm, the colonialpolitical space cultivates (im)mobile homo sacer.

Notably, the colonized movements are necessarily restricted as mere "animal reaction and fulfillment of functions." This restriction prevents the colonized from traveling as political subjects not only as a recognition of their movement as a political threat but as a consequence of unwavering adherence to the colonial relation of dominance/subordination. In this respect, colonial biopower can mold the colonized at best as "subpopulations" that are mobilizable and sacrificeable, not political subjects invested with political rights. In this regard, for instance, the enforcement of the 1937 policy of "Japan and Korea as one body," the "naisen-ittai" (內鮮一體), elicited the expectation of the abolition of the colonial relation of dominance/subordination from the Korean intellectuals. However, its motive was only to mobilize the colonized to the imperialistic warfare or businesses, denominating them as loyal Japanese subjects, not to eliminate the discrimination between the Japanese and the Korean by vesting the latter with the same political rights as the former. ${ }^{49}$

From the aquarium as a paradigm of political space, Kim's novel shows the colonial-political space's barrenness in which citizens trade their political rights for the right to mobility. Considering that citizens (un)consciously restrict their movements within "animal reaction and fulfillment of functions," the right to mobility in the colonial-political space would be deemed merely the rationalization of the deprivation of political rights, the dehumanized and animalized constitution and management of the colonial society. More significantly, the colonial-political space's barrenness demonstrates its insubstantiality, which ultimately originates from categorically excluding political subjects. Given its barrenness that prevent the colonized from moving as human subjects with political rights, the colonial-political space must be suffered from the shortage of its sincere subjects, probably, ensuring the colonial regime's continuity. However, the

49 Seungil Lee, Legislative Policy of the Japanese Government-General of Korea (Seoul: Yuksabipyeongsa, 2008), 307-315.

(c) 2021 Jinhyoung Lee https://www.kritike.org/journal/special issue 2021/j lee2 april2021.pdf ISSN 1908-7330

(c) $)$ BY-NC-ND 
colonial regime's maintenance itself seems to be absurd due to its dehumanizing nature as a result of its mobility biopolitics.

The society's barrenness and insubstantiality might be recovered most of all by human movements seeking "more than animal reaction and fulfillment of functions," more precisely, their movements for more than the right to mobility, which entails the abolition of the colonial regime, that is, the decolonized-humanized formation of society. Thus, their mobile practice would be framed in the politics of "more than."

\section{Contesting Maps and the Politics of "More Than"}

By examining Namcheon Kim's novel, The Aquarium of Love, in terms of the right to mobility, this paper identified the aquarium as a paradigm of colonial-political space. In this novel, Kim portrayed Korean society around 1940 as not only the mobile but also the colonial-political space in which Japanese colonialism asserts its power via the right to mobility, thereby molding the colonized as mobile citizens (colonial subjects) and as immobile non-citizens (the sacred lives, including the poor and threats). However, the novel uses the metaphor of fish, which (un)consciously practice "sheer political thoughtlessness" in order to not be expelled from society or to survive therein and whose movements are restricted within "animal reaction and fulfillment of functions" for the colonized deprived of political rights. Thus, the aquarium paradigm critically views mobility biopolitics, adopted by Japanese colonialism, as reducing the colonized to fish and, thus, disclosing the colonial space's barrenness and insubstantiality that originates from its categorical exclusion of political subjects.

Three maps appear in Kim's novel. In the late 1930s, Ilsung Shin, a swindler, utilized the map of Seoul to defraud people out of their money, using urban development information. The map shows the Japanese Government-General of Korea's plan to expand Seoul to Incheon for military purposes..$^{50}$ Kwangho's map of Manchuria, drawn by using an aerial survey, was a blueprint for the railroad construction. Despite his supposed apolitical use of the map, it would assist in Japanese imperialism's territorial expansion in Manchuria. Kwangjun had a map of the world that helped him to think about its present and future, used mainly to explore international political relations just before World War II.

These maps display the diversity of cartography by visualizing Seoul, Manchuria, and the world. Whereas the maps of Seoul and Manchuria

${ }^{50}$ In the late 1930s, the Japanese Government-General of Korea hurried to enforce the policy of expanding Seoul to the nearby cities officially in order to facilitate commandeering populations and artifacts to the warfare, broadening its coverage of mobility. Bokkyu Yum, The Origin of Seoul, the Birth of Keijo (Seoul: Idea, 2016), 335-367.

(c) 2021 Jinhyoung Lee https://www.kritike.org/journal/special issue 2021/j lee2 april2021.pdf

ISSN 1908-7330 


\section{MOBILITY BIOPOLITICS}

present the cities "inside" or "within" Japanese imperialism, a map of the world materializes the globe "outside" or "beyond" them. Thus, while the former involves restricting the colonized populations' movements within "animal reaction and fulfillment of functions," the latter encourages them to travel to seek "more than" their current status, albeit probably following their expulsion from society, as shown by Kwangjun's death. In this respect, the cartographical diversity would denote the possibility of designing an alternative to the current colonialist or imperialist map, one that seeks what is "more than."

In this light, in the epilogue, Hyunsoon Kang, the younger sister of Kwanjun's girlfriend, after failing to date Kwangho and determining not to participate in Kyunghee's public nursery, then decides to travel to Manchuria, looking forward to a new life. On the other hand, Kwangshin, removed from school, decides to move down to the country to study outside Seoul. Their movements first may be interpreted as the colonial biopower's abandonment of them. However, from Hyunsoon's and Kwanjun's selfconscious decision to leave colonial Korea, their movements can also be considered flights from the aquarium. Considering her movement to Manchuria to escape Kwangho, Kyunghee, and Korean society, it seems that Hyunsoon will not depend on Kwangho's map. Similarly, Kwangshin's journey will not be guided by the existing maps. Thus, their mobilities can be rendered as physically designing an alternative space to the colonial constitution of space.

Hyunsoon and Kwangshin take advantage of their mobility to leave the barren and insubstantial colony. However, their cartography is not likely to materialize as long as the colonial regime remains in power. Considering their destinations, their mobilities are likely to end in failure or death. Thus, the aquarium paradigm allows us to ponder upon the political space in which (im)mobile humans precariously lean toward either animal or death, that space that drive humans to seek for a being that is "more than" animals, risking their lives.

The Academy of Mobility Humanities, Konkuk University, South Korea

\section{References}

Agamben, Giorgio, Homo Sacer, trans. by Daniel Heller-Roazen (Stanford: Stanford University Press, 1998).

Arendt, Hannah, The Origins of Totalitarianism (San Diego: Harcourt Brace Jovanovich, 1976).

, Eichmann in Jerusalem (London: Penguin Books, 2006).

(c) 2021 Jinhyoung Lee

https://www.kritike.org/journal/special issue 2021/j lee2 april2021.pdf

ISSN 1908-7330

(cc) BY-NC-ND 
Choi, Hyerim, "A Study on the Meaning of Everyday Life Represented in Sarang-Eui Sujokwan (The Aquarium of Love) Written by Nam-Cheon, Kim," in Journal of Korean Literary History, 25 (2004).

Cresswell, Tim, "The Right to Mobility: The Production of Mobility in the Courtroom," in Antipode, 38 (September 2006).

Foucault, Michele, Security, Territory, Population, ed. by Michel Senllart, trans. by Graham Burchell (New York: Picador, 2007).

Fujitani, Takashi, Race for Empire (Berkeley: University of California Press, 2011).

Hwang, Hye-Young, "Gyeong Seong Guidance League's Establishment and Management during the 1930s-1940s," in Yeoksa Yeongu, 22 (June 2012).

Jang, Shin, "Travel Forbidden in Joseon under Japanese Occupation: A Study on the Transit Police," in Journal of Humanities, 25 (August 2017).

Kim, Myunggoo, "The Acceptance and Its Logic of 'Naeseon Ilchae' Theory/Propaganda in Joseon during the Period of the Sino-Japanese War," in The Journal for the Studies of Korean History, 33 (November 2008).

Kim, Namcheon, The Aquarium of Love (Keijo: Inmunsa, 1940).

"Problems of Character and Monomania," in Namcheon Kim's Collected Works, ed. by Ho-Ung Jung and Jeong-Soo Son (Seoul: Pagijong Press, 2000).

"Essay on the Literature of Observation," in Namcheon Kim's Collected Works, ed. by Ho-Ung Jung and Jeong-Soo Son (Seoul: Pagijong Press, 2000).

Kim, Yunmi, "Wartime Munitions Securement and Korean Labor Mobilization," in The Historical Association for Soong-Sil, 25 (2010).

Lee, Jinhyoung, "Colonial Mobility and the Biopolitics of the Colonial NonPlace," in Kritika Kultura, 36 (2021).

Lee, Seungil, Legislative Policy of the Japanese Government-General of Korea (Seoul: Yuksabipyeongsa, 2008).

Lee, Yunjin, "The Viewpoint of Women through Child-Care Policy during Japan's Occupation of Korea," in Journal of Asian Women's Studies, 42 (2003).

Orfeuil, Jean-Pierre, "The 'Right to Mobility', Now and in the Future," in Mobile/Immobile Quels Choix, Quels Droits pour 2030 1, ed. by Christophe Gay, Sylvie Landriève, and Stéphanie Vincent-Geslin (La Tour d'Aigues : Éditions de l'Aube, 2011).

Pandey, Gyanendra, "Introduction: The Subaltern as Subaltern Citizen," in Subaltern Citizens and Their Histories, ed. by Gyanendra Pandey (New York: Routledge, 2010).

(c) 2021 Jinhyoung Lee https://www.kritike.org/journal/special issue 2021/j lee2 april2021.pdf

ISSN 1908-7330 


\section{MOBILITY BIOPOLITICS}

Park, Jinsook, "The Aspects and Meanings of Textualization in the Novels in the Late Period of Japanese Rule over Korea," in Gaesin Language and Literature Research, 32 (2010).

Park, Myoungkyu, Nation, People, and Citizen (Seoul: Sowha, 2009).

Pearce, Lynne, "'Walking Out': The Mobilities of Love," in Mobilities, 13 (2018).

Sheller, Mimi, Mobility Justice (London: Verso, 2018).

Son, Jeongmok, A Study on the Urban Society under the Japanese Occupation (Seoul: Iljisa, 1996).

Stoler, Ann Laura, Duress: Imperial Durabilities in Our Times (Durham: Duke University Press, 2016).

Urry, John, Mobilities (Cambridge: Polity, 2007).

Viard, Jean, "Mobility, the Culture of Modern Times," in Mobile/Immobile Quels Choix, Quels Droits pour 2030 2, ed. by Christophe Gay, Sylvie Landriève, and Stéphanie Vincent-Geslin (La Tour d'Aigues: Éditions de l'Aube, 2011).

Yum, Bokkyu, The Origin of Seoul, the Birth of Keijo (Seoul: Idea, 2016). 